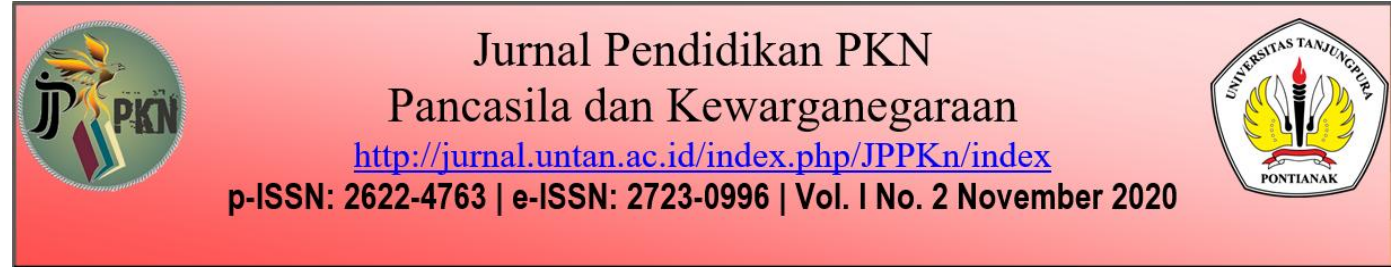

\title{
SEJARAH PERKEMBANGAN POLITIK LUAR NEGERI INDONESIA MASA PASCA REFORMASI
}

\author{
Nasihatul Mila ${ }^{1}$, Fatma Vida ${ }^{2}$, Depict Pristine Adi ${ }^{3}$ \\ 1,2,3 Institut Agama Islam Negeri (IAIN) Jember, Jl. Mataram No. 1, Kaliwates, \\ Jember, 68133, Indonesia \\ 1Nasihatulmila07@gmail.com
}

\begin{abstract}
ABSTRAK
Studi ini mengkaji tentang sejarah perkembangan politik luar negeri Indonesia masa pasca reformasi. Politik luar negeri Indonesia berarti setiap kebijakan Pemerintah Indonesia dalam menjalankan hubungan dengan dunia internasional demi mencapai tujuan nasional. Sejarah dan perkembangan politik luar negeri di Indonesia mengalami perubahan yaitu dimulai sejak awal kemerdekaan, pada masa pemerintah Soekarno dan Moh Hatta, hingga pada masa sekarang yakni pemerintahan Jokowi. Perubahan politik luar negeri Indonesia dapat dipengaruhi oleh kondisi negara, kepemimpinan pada masa tersebut dan dinamika situasi internasional. Namun, disini penulis berfokus pada masa pasca reformasi, karena pada masa itu struktur dan strategi politik luar negeri Indonesia mulai berubah. Tulisan ini berupaya menjelaskan sejarah perkembangan politik luar negeri Indonesia pada masa pasca reformasi. Dengan tulisan ini diharapkan dapat mengetahui arah kebijakan politik luar negeri Indonesia pada masa setelah berakhirnya orde baru tersebut. Penelitian ini menggunakan metode studi kepustakaan, di mana penulis mengumpulkan informasi yang relevan dengan topik yang menjadi objek penelitian. Hasil penelitian menunjukkan bahwa kebijakan politik luar negeri Indonesia pada masa pasca reformasi masih menggunakan formula yang sama dengan pemerintahan-pemerintahan sebelumnya, namun dalam era ini demokrasi dipandang lebih ditegakkan dari pada sebelumnya. Pemerintah selalu berusaha membuat kebijakan-kebijakan yang harus disesuaikan dengan situasi di dalam maupun di luar negeri dengan selalu berpegang pada prinsip bebas-aktif tanpa meninggalkan aspirasi masyarakat. Dengan begitu, pemerintah telah memperjuangkan berbagai kepentingan nasional terhadap dunia Internasional dengan maksud mencapai tujuan nasional.

Kata kunci: Masa Pasca Reformasi, Politik Luar Negeri
\end{abstract}


Jurnal Pendidikan Pancasila dan Kewarganegaraan

Volume I Nomor 2 (November) 2020

\begin{abstract}
This study examines the history of the development of Indonesia's foreign policy in the post-reform era. Indonesia's foreign policy is every policy of the Government of Indonesia taken in carrying out relations with the international world in order to achieve national goals. The history and development of foreign policy in Indonesia underwent a change that began from the beginning of independence, during the Soekarno and Moh Hatta governments, to the present, namely the Jokowi government. Changes in Indonesia's foreign policy can be influenced by state conditions, leadership at the time and the dynamics of the international situation. However, here the author focuses on the postreform era, because at that time the structure and strategy of Indonesia's foreign policy began to change, there was a restructuring of the Ministry of Foreign Affairs institutions becoming more open and transparent. This paper seeks to explain the history of the development of Indonesia's foreign policy in the post-reform era. With this paper, it is expected to find out the direction of Indonesia's foreign policy in the period after the end of the new order. This study uses a literature study method, in which the author collects information relevant to the topic that is the object of research. The results showed that Indonesia's foreign policy in the post-reform era still used the same formula as previous governments, but in this era democracy was seen as being more enforced than before. The government is trying to make policies that must be adapted to the situation at home and abroad by sticking to the principle of free and active without leaving the aspirations of the people. That way, the government has championed various national interests towards the international world with the intention of achieving national goals.
\end{abstract}

Keywords: Foreign Policy, Post-Reformation Period

\title{
PENDAHULUAN
}

Setiap negara di dunia mempunyai kebijakan dalam mengatur pemerintahannya. Bukan hanya perihal masalah dalam negeri saja. Pemerintah pun patut mengatur hubungannya dengan berbagai pihak di kancah Internasional agar keberadaannya diakui dan dapat menjalin hubungan baik dengan negara lain dan berbagai organisasi Internasional yang berpengaruh di dunia. Kebijakan-kebijakan tersebut biasa disebut dengan politik luar negeri.

Setiap negara yang berdaulat, pastilah akan mengatur kebijakannya mengenai hubungannya dengan dunia Internasional, baik itu dengan negara lain maupun organisasi yang berpengaruh di dunia Internasional. Kebijakan itu adalah bagian dari politik luar negeri yang dilaksanakan oleh suatu negara dan merupakan penggambaran dari kepentingan nasionalnya. Begitupun dengan Indonesia, sebagai suatu negara yang berdaulat, juga melaksanakan politik luar negeri dimana kebijakankebijakannya akan selalu berkembang menurut kebutuhan dalam negeri 
Jurnal Pendidikan Pancasila dan Kewarganegaraan

Volume I Nomor 2 (November) 2020

dan berubahnya situasi serta kondisi internasional. Setiap periode pemerintahan, pasti mempunyai pandangan yang bermacam-macam terhadap prinsip yang menjadi pegangan dalam pelaksanaan politik luar negeri Indonesia. Adanya perbedaan pandangan tersebut dapat dipengaruhi oleh kondisi di dalam maupun di luar negeri, sehingga kebijakan-kebijakan yang dibuat dapat berjalan sesuai harapan pemerintah dan masyarakat Indonesia.

Begitupun dengan Indonesia, sebagai negara yang merdeka dan berdaulat patut mengatur hubungan dengan dunia internasional. Hal itu pun diatur pada UU No. 37 tahun 1999 tentang Hubungan Luar Negeri. Politik luar negeri Indonesia bertujuan untuk memperjuangkan kepentingan nasional serta tercapainya tujuan nasional, khususnya dalam hal pembangunan nasional. Seiring dengan berkembangnya dunia Internasional, setiap negara memperjuangkan kepentingan nasionalnya melalui perundingan di tingkat bilateral, regional, maupun multilateral. Begitupun dengan Indonesia, pemerintah harus cerdas dalam memilih sikap dan menempatkan posisi Indonesia dalam lingkup dunia internasional. Target jangka pendek serta jangka panjang yang ingin dicapai dalam menjalankan kepentingan nasional ini perlu dirancang terlebih dahulu agar jelas terlihat biaya dan manfaatnya. Mengingat akan pentingnya sebuah strategi dalam menjalankan politik luar negeri Indonesia, kita perlu belajar dari kejadian dan peristiwa masa lalu yang akan mengantarkan Indonesia untuk kestabilan dan keteraturan hubungan dengan dunia Internasional meskipun terdapat perubahan situasi Internasional maupun domestik dari masa ke masa. Apalagi perubahan mencolok dari masa lahirnya reformasi di Indonesia.

Masa transisi pemerintahan pada masa berakhirnya pemerintahan orde baru yang kemudian melahirkan reformasi ini sangat berpengaruh terhadap pola pemerintahan di Indonesia. Masa ini mengubah bukan hanya pada politik yang dijalankan di dalam negeri, tetapi juga strategi dalam menjalankan politik luar negeri. Era reformasi ini diawali dari pemerintahan Presiden B. J. Habibie, Gus Dur, Megawati, SBY, dan sekarang Jokowi. Berdasarkan latar belakang tersebut, permasalahan yang muncul ialah bagaimana sejarah perkembangan politik luar negeri Indonesia masa pasca reformasi? Tulisan ini selanjutnya menjelaskan mengenai sejarah perkembangan politik luar negeri Indonesia masa pasca reformasi. 
Jurnal Pendidikan Pancasila dan Kewarganegaraan

Volume I Nomor 2 (November) 2020

\section{METODE PENELITIAN}

Metode yang digunakan adalah studi kepustakaan. Penelitian dengan menggunakan kajian pustaka tentu saja bukan hanya sekedar membaca dan mencatat literatur. Namun data pustaka yang diperoleh dari berbagai literatur mulai dari buku, jurnal, maupun internet diolah sehingga menjadi karya ilmiah yang dapat bermanfaat bagi pembaca.

Jadi, studi kepustakaan mempunyai arti kajian teoritis yang diambil dari beberapa referensi buku serta literatur ilmiah lainnya yang berhubungan dengan norma, nilai, dan budaya yang berkembang bersamaan dengan kondisi sosial ketika melaksanakan sebuah penelitian. Dan studi kepustakaan sangat penting dalam melakukan penelitian, karena dalam penelitian diperlukan literatur-literatur ilmiah untuk mendukung penelitian tersebut (Sugiyono, 2012).

Studi kepustakaan yang dilaksanakan sebelum malakukan penelitian bertujuan untuk:

1. Menemukan suatu masalah yang akan diteliti, yaitu mencari topik masalah yang sekiranya belum ada yang meneliti atau topik masalah tersebut belum terpecahkan secara memuaskan.

2. Mencari data yang relevan yaitu informasi yang sekiranya berkaitan dengan masalah yang akan diteliti.

3. Mengkaji teori-teori dasar yang berkaitan dengan masalah yang akan diteliti (Setiawan, 2020).

Peneliti akan melakukan penelitian dengan menggunakan metode penelitian studi kepustakaan baik sebelum maupun selama melakukan penelitian. Dalam hal ini, peneliti mengkaji setiap perkembangan politik luar negeri Indonesia masa pasca reformasi yakni mulai dari masa pemerintahan B. J. Habibie sampai pada masa pemerintahan yang sekarang berjalan dengan mengumpulkan, membaca, membandingkan, serta mengolah literatur yang tersedia, mulai dari buku-buku hingga artikel yang dipublikasikan dalam jurnal ilmiah.

\section{HASIL DAN PEMBAHASAN}

\section{Kajian Literatur}

\section{Hakikat Sejarah Politik}

Sejarah merupakan cerita tentang kehidupan manusia pada masa lampau yang disusun secara sistematis, kronologis, dan objektif berdasarkan bukti-bukti yang kredibel (Pramono, 2014). Sejarah membahas manusia dalam lingkup waktu. Waktu adalah unsur penting dalam sejarah. Setiap sejarah mengandung peristiwa yang 
penting dan patut dikenang serta diambil hikmahnya oleh setiap orang. Peristiwa penting tersebut pastilah terjadi dalam lingkup waktu tertentu. Dengan demikian, waktu dalam sejarah memunculkan pandangan mengenai peristiwa-peristiwa yang terjadi dan mampu mengenang masa lalu yang dipandang mempunyai nilai. Sejarah umat manusia sesungguhnya merupakan proses perkembangan manusia dan segala budayanya dalam lingkup waktu.

Waktu berarti perubahan, dan seluruh isi semesta alam, tidak terkecuali umat manusia dan segala budaya yang lahir darinya, mengalami perubahan yang terus menerus mengikuti perkembangan zaman. Sejarah merupakan ilmu yang memperlihatkan bahwa tidak ada satu gagasan apapun yang kekal sepanjang masa. Sejarah tidak akan memiliki arti jika segala sesuatu dalam keadaan tetap.

Sejarah juga membahas manusia dalam lingkup ruang. Baik sebagai individu maupun kelompok bangsa, manusia dipelajari dalam konteks lingkungan fisik dan geografis. Interaksi antara manusia dan lingkungan alam berjalan secara dinamis. Interaksi ini menghasilkan berbagai perkembangan pada aktivitas manusia dan pencapaiannya, baik di bidang politik, ekonomi, sosial, maupun kebudayaan.

Sejarah politik adalah analisis insiden-insiden politik, narasi, gerakan, ide dan para pemimpin yang umumnya disusun dari negara dan bangsa. Meskipun berbeda dengan ilmu sejarah, akan tetapi, masih berhubungan dengan ilmu sejarah lain seperti halnya sejarah militer, sejarah ekonomi, dan sejarah sosial.

Secara umum, sejarah politik dapat dikatakan sebagai peristiwa yang berkaitan dengan negara-negara dan proses politik. Menurut Hegel (dalam Tosh, 1991: 74), sejarah politik merupakan gagasan dan pandangan mengenai negara dengan kekuatan moral dan spiritual di luar kepentingan materi pelajaran, dalam hal ini dapat dikatakan bahwa negara adalah aktor utama dalam perubahan sejarah politik. Ini salah satu perbedaan dengan misalnya sejarah sosial, yang berpusat pada perilaku dan gaya hidup masyarakat (Siska, 2015).

\section{Hakikat Politik Luar Negeri}

Politik dapat dipahami sebagai proses pembentukan dan pembagian kekuasaan dalam masyarakat antara lain berwujud proses pembuatan keputusan, khususnya dalam negara. Lebih sederhananya, politik dapat dipahami sebagai proses interaksi antara pihak penguasa dan pihak yang dikuasai (Usman \& Setiadi, 2013). 
Politik terdiri dari kegiatan organisasi dalam hal mana manusia di dalamnya berusaha memaksimalkan keyakinan mereka mengenai nilai-nilai sosial. Melalui tindakan politis, manusia berusaha untuk sadar akan perbedaan pendapat mereka mengenai apa yang baik bagi masyarakat. Jadi politik dapat diartikan sebagai suatu usaha untuk mencapai suatu tujuan yang dilakukan oleh individu maupun organisasi. Suatu hal yang ingin capai dapat berupa suatu kekuasaan dan pengakuan dari pihak lain.

Definisi mengenai politik serupa ini adalah luas dalam penggunaannya terhadap berbagai tindakan manusia dalam hal politik. Jika suatu manusia tidak menyepakati terhadap suatu nilainilai sosial tersebut, maka akan terjadi perlawanan terhadap nilai-nilai tersebut. Jadi, tindakan politis itu bermacam-macam, mulai dari kerjasama dan persetujuan antara para pelaku politik, persetujuan sebagian, atau oposisi total hingga konflik. Para pelaku politik yang berpengalaman, mempunyai cara jitu dalam mengambil keputusan sehingga mendapat kepuasan nilai. Dalam menjalankan sebuah politik, masyarakat memerlukan para pemimpin yang bertindak atas nama masyarakat. Para pemimpin patutlah menyalurkan setiap aspirasi masyarakatnya. Agar aspirasi masyarakat yang diwakilkan pemerintah tersebut dapat dijalankan, baik dalam urusan di dalam maupun di luar negeri demi tercapainya tujuan nasional. Dalam hal ini, selain menentukan dan melaksanakan kebijakan di dalam negeri, pemerintah juga harus menentukan dan melaksanakan kebijakan di luar negeri tanpa meninggalkan aspirasi masyarakat.

Dengan demikian, politik luar negeri merupakan wewenang yang diberikan oleh pemerintah secara khusus. Sebab hanya pemerintah yang dapat bertindak dan bertanggung jawab atas nama seluruh rakyatnya.

Sedangkan isi dari tindakan pemerintah kepada dunia Internasional dipengaruhi oleh nilai-nilai sosial yang berada di masyarakat. Timbulnya nasionalisme menyebabkan politik luar negeri dalam satu seginya menjadi demokratik, karena pemerintah berkewajiban untuk menyusun usaha-usaha internasionalnya, agar menggambarkan nilai dari rakyat yang diwakilinya. Jadi nilai-nilai yang digunakan dalam melaksanakan politik luar negerinya berasal dari beraneka ragam sumber dan unsurnya. Maka para pejabat pemerintah berkewajiban dalam hal merumuskan kebijakan-kebijakan yang sesuai dengan kondisi negara tersebut dalam menjalankan 
politik luar negerinya. Berkenaan dengan itu, Para pejabat yang bertugas membuat kebijakan, berkewajiban untuk menyusun daftar kebutuhan dan kehendak, lalu membentuknya menjadi satu pernyataan dengan memakai sintesis nilai yang dibuatnya dalam fenomena politik internasional.

Politik luar negeri merupakan sebuah kebijakan nasional yang ditujukan untuk Internasional. Jadi politik luar negeri adalah kebijakan-kebijakan nasional yang mengandung kepentingan nasional yang ditujukan untuk dunia Internasional. Politik luar negeri ini dijalankan guna menjalin hubungan kerjasama dengan negara maupun organisasi di tingkat internasional.

Adanya perubahan Internasional yang secara dinamis, harus diwaspadai oleh setiap negara, agar negara yang menjalankan politik luar negerinya tidak terdapat hambatan. Sehingga pada akhirnya politik luar negeri suatu negara tersebut akan berjalan sesuai dengan tujuan nasionalnya (Syafaat, 2019).

Definisi lain politik luar negeri yaitu taktik suatu negara dalam menjalin hubungan dengan negara lain berdasarkan sikap, arah, nilai serta sasaran untuk melindungi, mensejahterakan, dan memajukan kepentingan nasional negara tersebut di dalam lingkup dunia internasional (Zakky, 2018). Dengan demikian, setiap negara pastilah mempunyai kebijakannya sendiri dalam menjalankan politik luar negeri negarinya. Perbedaan dalam menjalankan politik luar negeri suatu negara disebabkan oleh tujuan yang hendak dicapai oleh negara tersebut, seperti Undang-Undang yang mengatur tentang politik luar negeri disetiap negara pastilah tidak sama dengan negara lain.

\section{Politik Luar Negeri Indonesia}

Politik luar negeri Indonesia menganut prinsip politik luar negeri yang bebas aktif dalam mengusahakan kepentingan nasional Indonesia. Bebas bisa diartikan bahwa Indonesia tidak berpihak pada sisi manapun, Indonesia bebas dalam memilih kerja sama dengan pihak manapun selama hal itu sesuai dengan nilai-nilai luhur bangsa. Sementara aktif artinya Indonesia tidak akan tinggal diam saja tanpa melakukan apapun, namun aktif dalam mewujudkan ketertiban dunia dengan ikut serta dalam hubungan internasional.

Politik bebas aktif adalah ekstraksi dari kearifan para pendahulu diplomat Indonesia yang sudah mengakumulasi pengalaman pahit dan getir berinteraksi dengan major powers. Secara filosofis, Indonesia 
Jurnal Pendidikan Pancasila dan Kewarganegaraan

Volume I Nomor 2 (November) 2020

dipersepsikan sebagai negara yang cinta damai tapi yang lebih mencintai kemerdekaan. Rivalitas antar kekuatan dunia ditinjau sebagai bentuk perilaku yang berorientasi pada kepentingan masingmasing negara (self centered) tanpa memperdulikan kesulitan yang ditimbulkannya pada pihak lain, terutama negara-negara kecil (lesser states).

Pada abad ke 21 yang diwarnai dengan kebangkitan China (yang telah hadir menjadi rival terberat Amerika serikat) dan perkembangan regionalisme ASEAN yang semakin progresif dapat mengembangkan tripolar framing, yang menjadikan tiga kekuatan besar sebagai pedoman kebijakan politik luar negeri Indonesia, yaitu Amerika serikat, China, dan ASEAN. Ketiga polar ini dimanfaatkan kelebihan nya oleh pemerintah Indonesia bagi kepentingan Nasional dalam aspek ekonomi, militer, dan kedaulatan. Politik bebas aktif dipertahankan dan direvitalisasi sebagai platform yang dapat mengoptimalkan eksploitasi kepentingan Indonesia pada ketiga polar diatas (Yani \&Tama, 2017).

Dengan prinsip politik yang bebas aktif, Indonesia akan mudah menentukan kebijakan dan sikapnya sebagai sebuah negara yang merdeka dan berdaulat. Prinsip bebas aktif dalam menjalankan kebijakan politik luar negeri Indonesia disesuaikan dengan perubahan dan perkembangan baik dalam lingkup nasional, regional, maupun internasional (Elisabet, 2016). Terlebih lagi, perubahan yang dapat mempengaruhi perkembangan di tingkat Nasional. Dengan begitu, Indonesia berupaya memaksimalkan kontribusi internasional demi terselenggaranya kesejahteraan masyarakat Indonesia maupun dunia. Maka prinsip bebas aktif dilaksanakan secara lebih proaktif, pragmatis, fleksibel, asertif dan juga akomodatif.

Dewasa ini, politik dunia dikuasai oleh kekuatan yang saling bertentangan, yakni Uni Soviet dan Amerika Serikat. Uni Soviet memiliki ideologi komunisme, sedangkan Amerika Serikat memiliki ideologi liberalisme. Seperti yang sudah dijelaskan di atas, bahwa politik luar negeri Indonesia yang bebas aktif, Indonesia tidak mau memilih dan mendukung salah satu pihak.

Landasan yang dijalankan Indonesia dalam politik luar negerinya terdapat 3 landasan diantaranya:

\section{a. Landasan Idiil}

Dalam landasan idiil yakni berupa Pancasila. Pancasila selain sebagai dasar Negara Indonesia dijadikan pula sebagai landasan 
politik luar negeri Indonesia. Dengan berlandaskan kelima sila dalam Pancasila, akan memberikan pedoman dan arahan dalam pelaksanaan politik luar negeri.

Sila pertama yakni, "Ketuhanan yang Maha Esa". Sebagai makhluk tuhan yang berpegang teguh, percaya, dan menjalankan ajaran tuhan, bangsa Indonesia senantiasa memegang prinsip ketuhanan dalam Pancasila dalam melaksanakan pemerintahan dan juga kehidupan bernegara.

Sila kedua, "Kemanusiaan yang Adil dan Beradab". Indonesia pada hal ini menjunjung tinggi keadilan tanpa membeda-bedakan status sosial dalam masyarakat dan bangsa-bangsa di dunia, dan menentang keras akan adanya kekerasan dan penindasan yang terjadi di seluruh dunia.

Sila ketiga, "Persatuan Indonesia". Dalam hal ini bangsa Indonesia yang terlahir sebagai bangsa yang multikultur siap bersatu demi menjalankan kepentingan nasional, dan mengutamakan kepentingan nasional tersebut di atas kepentingan pribadi, suku maupun golongan.

Kemudian sila keempat, yang berbunyi "Kerakyatan yang Dipimpin oleh Hikmat, Kebijaksanaan dalam Permusyawaratan/Perwakilan". Menurut sila keempat ini, bangsa Indonesia mengedepankan sistem musyawarah dan perundingan dalam menyelesaikan masalah, dengan begitu permasalahan akan terselesaikan dengan kepala dingin.

Sila kelima, "Keadilan Sosial bagi Seluruh Rakyat Indonesia". Dalam menjalankan politik luar negerinya, Indonesia juga berprinsip pada sila kelima ini, yakni memegang teguh prinsip-prinsip keadilan.

\section{b. Landasan Konstitusional}

Selain Pancasila, Indonesia juga mempunyai landasan konstitusional yakni berupa Undang-Undang (UUD) 1945 dalam pembukaan dan batang tubuh. Pada pembukaan UUD 1945 menjadi landasan di alenia pertama dan keempat, sedangkan pada bagian tubuh menjadi landasan pada pasal 11 dan 13.

Alenia pertama pada pembukaan UUD 1945 berbunyi, "Bahwa sesungguhnya kemerdekaan itu ialah hak segala bangsa, dan oleh sebab itu maka penjajahan di atas dunia harus dihapuskan karena tidak sesuai dengan perikemanusiaan dan perikeadilan." Juga alenia keempat yang berbunyi, 
Jurnal Pendidikan Pancasila dan Kewarganegaraan

Volume I Nomor 2 (November) 2020

"dan ikut melaksanakan ketertiban dunia yang berdasarkan kemerdekaan, perdamaian abadi, dan keadilan sosial."

Selain terdapat pada pembukaan UUD 1945, landasan konstitusional juga ada pada Pasal 11 UUD 1945 yang berbunyi, "Presiden dengan persetujuan Dewan Perwakilan Rakyat menyatakan perang, membuat perdamaian, dan perjanjian dengan negara lain." Serta Pasal 13 UUD 1945 yang berbunyi, "Presiden mengangkat duta dan konsul." Dalam ayat 2 menjelaskan, "Dalam mengangkat duta, Presiden memperhatikan pertimbangan Dewan Perwakilan Rakyat," dan ayat 3 menjelaskan, "Presiden menerima penempatan duta negara lain dengan memperhatikan pertimbangan Dewan Perwakilan Rakyat."

\section{c. Landasan Operasional}

Selain Pancasila sebagai landasan idiil dan UUD 1945 sebagai landasan konstusional, Indonesia juga berlandaskan pada peraturan perundang-undangan sebagai landasan operasional. Dalam hal ini peraturan perundang-undangan yang menjadi landasan politik luar negeri Indonesia diantaranya:

1) UU No. 37 Tahun 1999 tentang Hubungan Internasional dan tentang Pertahanan Negara,

2) UU No. 24 Tahun 2000 tentang Perjanjian Internasional, undangundang ini mengatur tentang perjanjian internasional secara detail,

3) UU No. 25 Tahun 2004 tentang Sistem Perencanaan Pembangunan Nasional,

4) UU No. 17 Tahun 2007 tentang Rencana Pembangunan Jangka Panjang, Peraturan Pemerintah No. 20 tentang Rencana Kerja Pemerintah, dan Peraturan Presiden No 5 Tahun 2010 Tentang Pembangunan Jangka Menengah Nasional,

5) Keputusan Presiden Nomor 108 Tahun 2003 tentang Organisasi Perwakilan RI di Luar Negeri dan Keputusan Menteri Luar Negeri Nomor SK.06/A/OT/VI/2004/01 Tahun 2004 tentang Tata Kerja Perwakilan RI di Luar Negeri (Wilianto, 2020).

\section{Politik Luar Negeri Indonesia Pasca Reformasi}

\section{Politik Luar Negeri Indonesia Masa Pemerintahan B.J Habibie}

Politik luar negeri Indonesia mulai dari awal merdeka sampai sekarang banyak mengalami dinamika seiring dengan berubahnya pemegang kepemimpinan. Berbeda pemimpin, maka berbeda pula 
Jurnal Pendidikan Pancasila dan Kewarganegaraan

Volume I Nomor 2 (November) 2020

karakteristik dan fokus politik luar negerinya. Kegley menjelaskan bahwa sesuatu yang dapat memengaruhi penyusunan kebijakan luar negeri ada tiga yakni antara lain kondisi domestik, kondisi internasional, dan karakter pemimpin.

Pada awal masa pemerintahan Presiden Habibie menunjukkan kepemimpinannya yang berbeda, pendekatan yang digunakan Presiden Habibie berbeda dengan pendekatan yang diterapkan oleh pemerintahan Soeharto. Melalui kebijakan yang diambil oleh Presiden Habibie dapat memperlihatkan komitmen dan perhatian terhadap reformasi untuk memperbaiki dan mengatasi kondisi negara saat itu.

Dukungan Presiden Habibie kepada liberalisasi partai-partai politik, kebebasan pers, dan melanjutkan kerjasama dengan organisasi multilateral seperti IMF, IDB, ADB, World Bank, dan ILO. Juga kebijakan desentralisasi dengan memberikan pengalihan kekuasaan ke berbagai daerah menunjukkan komitmen Presiden Habibie dalam proses reformasi dan pembangunan Indonesia (Hamonangan, 2018).

Agenda politik luar negeri Indonesia masa Presiden Habibie dengan menteri luar negerinya Ali Alatas merumuskan kebijakan sebagai berikut:

a. Mengusahakan dukungan dana dari Dana Moneter Internasional (IMF) untuk pemulihan ekonomi Indonesia.

b. Menyelesaikan masalah dengan Timor Timur dengan tuntas.

c. Meningkatkan peranan Indonesia dalam ASEAN (Mohsin, 2019).

Dalam usaha untuk mendapatkan bantuan dari negara-negara maju dan dukungan dari IMF untuk pemulihan perekonomian Indonesia, terus meningkatkan hubungan diplomasi ekonomi. Diplomasi ekonomi tersebut mencakup peningkatan kegiatan ekspor Indonesia ke luar negeri, menarik investor asing terutama dalam bentuk FDI, dan meningkatkan promosi tempat wisata di Indonesia untuk menarik wisatawan asing agar berkunjung ke Indonesia.

Saat Habibie menjadi presiden, juga terdapat masalah yang sangat urgen yaitu mengenai otonomi Provinsi Timor Timur. Sejak 17 Juli 1976, Timor Timur resmi menjadi bagian dari NKRI (Hidayat, 2020). Namun pada tanggal 30 Agustus 1999, Presiden Habibie mengadakan jajak pendapat yang dilakukan atas usulan PBB. Hasil dari jajak pendapat tersebut adalah sebagian besar masyarakat Timor-Timur menolak otonomi khusus yang ditawarkan Indonesia. Sehingga dalam sidang umum MPR pada tahun 1999, MPR RI memutuskan mencabut TAP MPR No. VI/1978 dan mengembalikan Timor Timur seperti pada 
Jurnal Pendidikan Pancasila dan Kewarganegaraan

Volume I Nomor 2 (November) 2020

tahun 1975. Dengan kata lain, Provinsi Timor Timur lepas dari NKRI dan menjadi sebuah Negara yang bernama Timor Leste.

Kebijakan Habibie tersebut menjadi pertanda berakhirnya perang antara militer Indonesia dengan Fretilin (Frente Revolucionaria de Timor-Leste Independente) yaitu kelompok pro kemerdekaan Timor Timur. Peristiwa itu terjadi sejak tanggal 7 Desember 1975 (Ansyari, 2019).

Di samping itu, peran Indonesia dalam ASEAN pada masa pasca reformasi 1998 pada bidang politik adalah bagaimana Indonesia dapat memiliki kemampuan untuk menentukan arah politik ASEAN agar dapat bersinergi di kancah internasional dalam usaha menggapai kesejahteraan bagi masyarakat Indonesia. Dalam hal ini, Indonesia berupaya meningkatkan peranannya dalam ASEAN.

Terlepas dari itu semua, capaian Presiden B. J. Habibie semasa jabatannya juga patut dibanggakan. Presiden yang dijuluki bapak demokrasi tersebut banyak mengeluarkan undang-undang dan surat keputusan yang dirasa penting dalam kebebasan dan kemajuan berdemokrasi di Indonesia, diantaranya adalah: (1) Undang-Undang Kebebasan Pers No. 40 Tahun 1999, (2) Undang-Undang Otonomi Daerah No. 20 Tahun 1999, (3) Undang-Undang Partai Politik No. 2 Tahun 1999.

\section{Politik Luar Negeri Indonesia Masa Pemerintah Abdurrahman Wahid (Gus Dur)}

Sejalan dengan role theory, penguasa suatu negara akan banyak dipengaruhi oleh individu dan kelompok yang ikut serta dalam mengambil sebuah kebijakan. Dalam hal ini, Abdurrahman Wahid atau biasa dikenal Gus Dur ini sebagai presiden mempunyai dua peran yaitu kepala negara dan kepala pemerintahan Repulik Indonesia yang mengambil peran ini dan menjadi aktor dominan dalam menentukan identitas serta mengambil keputusan dalam menjalankan politik luar negeri Indonesia kala itu. Dalam tataran teoritis, identitas politik luar negeri RI tidak hanya dapat berkaca pada pengambilan keputusan dengan gaya "bureucratif polity" melainkan juga pada rational actor yang mengambil peran dan pengaruhnya terhadap penentuan arah kebijakannya.

Dalam hal ini, dengan prinsip rational actor yang cenderung mendominasi pemerintahan, Gus Dur menjadikan karakter birokrasi di Indonesia menjadi cukup lemah, dari segi soliditas maupun dari 
segi kemampuan untuk merespon persoalan. Sebab, Gus Dur dengan karakternya yang kuat menjadikan figur presiden lebih dominan dan mempengaruhi pemerintahan. Presiden membayangi tindakan birokrasi sehingga keberadaan birokrasi ini terlihat lemah. Begitupun dengan tindakan-tindakan mengenai politik luar negeri, hal itu tidak terlepas dari gaya kepemimpinan Gus Dur ini.

Beberapa saat setelah Gus Dur dilantik menjadi Presiden RI, dalam urusannya menangani politik luar negeri ia mempunyai beberapa kebijakan, yang dalam hal ini seakan membuat pergeseran politik luar negeri Indonesia, beberapa diantaranya seperti: dicetuskannya rencana penguatan hubungan dengan Israel, dan mengenai gagasannya yang berkenaan dengan pembentukan aliansi strategis Indonesia-Cina-India, gagasan ini disampaikannya ketika ia mengadakan kunjungan ke beberapa negara di Asia.

Identitas politik luar negeri yang dibangun oleh Presiden Abdurrahman Wahid ini memang sering kali menjadi sorotan publik karena begitu khas. Dalam melaksanakan peraturan politik luar negeri selama dua tahun menjabat sebagai presiden RI, Gus Dur mengambil peran "aktor utama" (chief diplomat). Hal ini dikarenakan padatnya aktivitas kunjungan presiden ke luar negeri. Bahkan, tercatat rekor kunjungan hingga lebih dari 50 negara dilima benua. Gus Dur dapat dikatakan sebagai presiden RI pertama yang mampu mengunjungi 5 benua di dunia dalam rangka menjalankan diplomasi sebagai tugas politik luar negeri Indonesia yang harus dijalankan (Widhiyoga \& Harini, 2019). (Hal itu mendapat kritikan dari ketua MPR Amin Rais dan ketua DPR Akbar Tandjung karena dirasa kurang memperhatikan masalah domestik, seperti konflik aceh. Namun Gus Dur menjawab bahwa kunjungannya ke luar negeri bertujuan untuk mengembalikan nama baik Indonesia, berharap investor internasional menanamkan modal lagi, dan mencari dukungan internasional terhadap keutuhan Aceh yang merupakan bagian dari NKRI.

Pemerintahan masa Gus Dur pada saat itu Indonesia memasuki tahapan baru. Pemerintahan ini di anggap paling kontroversial, karena Gus Dur ingin menjalin hubungan kerjasama dengan Negara Israel. Namun hal tersebut mendapat penolakan dari dalam negeri (Sudarso, 2020). Orang bisa saja beramsumsi mengenai Gus Dur tentang hal yang tidak baik, tetapi ada suatu hal penting serta harus kita ketahui, Gus Dur punya alasan kenapa dia ingin berkerjasama dengan Yahudi. Berikut ini alasan Gus Dur ingin bekerjasama dengan 
Jurnal Pendidikan Pancasila dan Kewarganegaraan

Volume I Nomor 2 (November) 2020

Yahudi, (1) Tertarik pada bidang keilmuan Yahudi, ketertarikan tersebut berawal ketika Gus Dur belajar di Universitas Baghdad, Irak. Disana ia mendapat teman diskusi yang baik yang bernama Ramin, merupakan keturunan dari minoritas Yahudi di Irak. Dari sosok Ramin inilah Gus Dur mempelajari tentang kehidupan Yahudi seperti politik dan ekonominya; (2) Tertarik akan sebab Yahudi bisa pengaruhi Amerika dan dunia, menurut Mahfudz Ridwan (teman Gus Dur waktu di Baghdad), rasa persaudaraan Yahudi yang kuat dan tinggilah yang dapat menguasai dunia. Kemudian melihat dari firman Tuhan dalam beberapa kitab yang menyebutkan bangsa Yahudi sebagai bangsa yang ingkar kepada Tuhan. Stigma tersebut yang membuat Yahudi ingin memperlihatkan pengaruhnya dan dianggap oleh bangsa lain. Sebab itulah yang membuat Yahudi ingin mempunyai posisi yang kuat baik ekonomi maupun politik. Dan untuk mempengaruhi dunia, Yahudi melakukan pelobian serta memberi bantuan finansial kepada bangsa lain. (3) Gus Dur ikut serta dalam yayasan Simon Peres yang bertujuan untuk perdamaian dunia sejak ia menjadi ketua umum PBNU, hal itu ia teruskan ketika ia menjabat sebagai Presiden.

Gus Dur berkeinginan mengirim ribuan sarjana ke Israel karena saat itu Israel lebih maju dibanding Indonesia. Tujuan para mahasiswa yang dikirim ke Israel untuk mempelajari tata pemerintahan, politik, ekonomi dan pertanian. (4) Gus Dur dan beberapa temannya diundang untuk perjanjian damai Israel-Yordania oleh Perdana Menteri Israel Yitzhak Rabin, pada tahun 1994. Pada waktu itu, Gus Dur menyempatkan diri bertemu dengan beberapa warga di Israel. Pada saat itulah Gus Dur merasakan sebuah perasaan damai dan kuat dari warga Israel. Bahkan warga tersebut mengatakan "Hanya mereka yang berada dalam keadaan perang yang bisa merasakan apa makna kata damai" kepada Gus Dur. Setelah mendengar perkataan warga Israel ini Gus Dur menjadi tersentuh dan tergerak ingin membuat sebuah perdamaian antar Israel dan Palestina dengan mengutamakan win-win solution (Taufiq, 2013).

Pada masa ini, terdapat perkembangan positif yang berpengaruh pada pembuatan kebijakan luar negeri yaitu disahkannya UU No. 37 tahun 1999, tentang hubungan luar negeri, UU no. 24 tahun 2000 tentang Perjanjian Internasional, dan Keppres tentang Tata Koordinasi Penyelenggaraan hubungan luar negeri. 
Jurnal Pendidikan Pancasila dan Kewarganegaraan

Volume I Nomor 2 (November) 2020

\section{Politik Luar Negeri Indonesia Masa Pemerintahan Megawati}

Megawati adalah Presiden Indonesia setelah Presiden Abdurrahman Wahid. Dalam membangun dan mengurus suatu Negara, ia berusaha menyusun strategi dan rencana dalam menjalankan pemerintahannya serta mengedepankan kepentingan nasional demi meraih tujuan nasional Indonesia. Berkenaan pada politik luar negeri Indonesia ia memprioritaskan dan memegang teguh prinsip yang selama ini dipegang dalam melaksanakan politik luar negeri yakni prinsip bebas aktif, mengembalikan martabat bangsa dan negara di mata dunia, serta mengembalikan kepercayaan luar negeri terhadap Indonesia termasuk lembaga-lembaga pemberi pinjaman kepada Indonesia dan investor terhadap kegiatan pemerintah. Selain pada prioritas tersebut, Megawati juga menambahkan bahwa dalam menjalankan politik luar negeri Indonesia memerhatikan upaya pemulihan dan menjaga stabilitas keamanan dan pertahanan nasional Indonesia, sehingga Indonesia membutuhkan sistem yang efektif, disiplin, serta aparat keamanan, yang berada di bawah kendali pemerintah, namun tetap terinspirasi oleh aspirasi masyarakat.

Identitas politik luar negeri yang dibangun oleh Presiden Megawati menunjukkan kesan yang berbeda dengan Gus Dur. Sesuai dengan perbedaan pada karakter pribadinya, Megawati lebih banyak melimpahkan tugas diplomasi dan untuk menjalankan politik luar negeri kepada menteri luar negerinya. Hal tersebut dilaksanakan oleh Presiden Megawati karena sesuai dengan ketentuan birokrasi, Presiden Megawati memang dapat menunjuk figur menteri luar negeri yang memang sepenuhnya fokus bertugas pada hal-hal yang berhubungan pada kegiatan hubungan luar negeri.

Dalam menjalankan politik luar negeri Indonesia, Presiden Megawati menunjuk menteri luar negeri untuk menjalankan hubungan dengan luar negeri. Hal tersebut didasari pada UndangUndang Nomor 37 Tahun 1999 yang membahas tentang kegiatan luar negeri Indonesia, presiden bisa melimpahkan kewenangan mengenai kegiatan politik luar negeri kepada para menteri luar negeri yang menjadi perwakilan dan pemimpin dalam pelaksanaan hubungan politik luar negeri. Selain itu, sesuai dengan yang tercantum pada UUD 1945 pemerintahan Megawati dalam menjalankan politik luar negeri perlu memperhatikan dan mempertimbangkan peran DPR (Rachmianto, 2020). 
Berdasarkan kebijakannya itu, Megawati menunjuk Menteri Luar Negeri RI untuk bertugas dalam hal menangani politik luar negeri dan diplomasi yaitu Hasan Wirayuda. Berdasarkan kepercayaan presiden kepadanya, ia segera mencanangkan program Benah Diri dengan konsep Diplomasi Total. Tujuan dari diplomasi total ini adalah agar dapat melibatkan masyarakat untuk memerankan kegiatan diplomasi serta peraturan tentang luar negeri Indonesia. Implementasi dalam konsep hubungan diplomasi sepenuhnya memerlukan adanya kerjasama dari seluruh petinggi kekuasaan yang berasal dari dalam negeri. Tujuannya adalah untuk membuat dan menyusun kebijakan-kebijakan luar negeri yang bersifat integratif dalam pandangan intermestik internasional domestik. Diplomasi total akan menghendaki agar peraturan-peraturan tentang luar negeri yang dihasilkan tidak hanya berdasarkan peran kementerian luar negeri semata, melainkan juga diperankan oleh masyarakat sebagai bagian dari kebijakan diplomasi total.

Identitas politik luar negeri Indonesia masa ini menunjukkan bahwa presiden tidak memegang peran dominan, namun ia menyerahkan tugas tentang kegiatan politik luar negeri Indonesia kepada para menteri luar negeri untuk menjalankannya. Kegiatan dari politik luar negeri Indonesia juga masih tidak memiliki ketegasan, karena cenderung patuh terhadap pihak lain, yang dianggap memiliki position lebih tinggi dari Negara Indonesia, seperti IMF. Hal ini menimbulkan hubungan yang dekat dengan pihak Blok Barat, dikarenakan Blok Barat dan organisasinya lah yang banyak membantu dalam hal memulihkan stabilitas nasional Indonesia, sekalipun dengan mengajukan persyaratan khusus untuk dipatuhi Indonesia (Widhiyoga \& Harini, 2019).

Pada masa Presiden Megawati menjalin hubungan bilateral dengan Australia. Kerjasama tersebut banyak membantu terutama dibidang pertahanan dan keamanan. Pemerintah Indonesia dengan Australia menyepakati Memorandum of Understanding (MoU) on Combating International Terrorism yang ditandatangani oleh Abdurrahman Mattalitti yang mewakili Indonesia dan pada saat itu menjabat sebagai Direktur Jenderal Hubungan Sosial, Budaya dan penerangan, Dapartemen Luar Negeri, sedangkan untuk Australia diwakili oleh Richard Smith yang menjabat sebagai Duta Besar Australia untuk Indonesia, penandatanganan dilakukan pada hari Kamis 7 Februari 2002 di Jakarta. Alasan Australia melakukan 
Jurnal Pendidikan Pancasila dan Kewarganegaraan

Volume I Nomor 2 (November) 2020

hubungan bilateral Indonesia adalah pada saat itu Indonesia diteror oleh teroris yang melakukan pengebomannya di Bali. Pemerintah Australia bahwa peristiwa tersebut merupakan hal penting, karena dapat mengancam warganya di Bali dan mengancam keberlangsungan kegiatan ekonomi perusahan Australia yang berada di Indonesia (Junaidi \& Rochmat, 2018).

Sebagai upaya menjalankan diplomasi lain untuk menyakinkan masyarakat internasional terhadap pemerintah Indonesia dan memberikan kepercayaannya, usaha yang dilakukan Indonesia adalah dilihatkannya dalam mengatasi kasus-kasus Timor Timur dibuktikan juga dengan pembentukan KPPHAM Timor Timur dan pembentukan pengadilan HAM ad hoc berdasarkan Keputusan Presiden RI No. 96 tahun 2001, yang bertujuan memberikan pengadilan kepada kasuskasus yang melanggar HAM di Timor Timur. Dimana proses tersebut berjalan dengan menunjukkan bahwa pemerintahan Presiden Megawati cukup tanggap dalam mengikuti dan memperhatikan atas sorotan terhadap Indonesia sebagai hasil dari perubahan-perubahan ranah internasional akibat pasca perang dingin.

\section{Politik Luar Negeri Indonesia Masa Pemerintahan Susilo Bambang Yudhoyono (SBY)}

Sejalan dengan pergantian pemimpin pemerintahan, kebijakankebijakan politik luar negeripun terus diupayakan agar dapat mengembalikan perekonomian nasional yang berada pada tengahtengah globalisasi. Kegiatan politik luar negeri Indonesia sangat dianjurkan membahas kerjasama bilateral dengan negara-negara Asia Timur, ASEAN+3 (Jepang, Korea Selatan, dan Cina), East Asia Community dan APEC pada ranah regional, serta organisasi-organisasi tertentu pada ranah internasional.

Pada era pemerintahan Presiden SBY hubungan diplomasi antara Indonesia dengan Cina diinginkan agar lebih meningkat lagi dengan diwujudkannya Deklarasi Kemitraan Strategis antara Indonesia dan Cina. Indonesia berharap Cina dapat berfungsi sebagai pasar yaitu Cina dapat menerima produk Indonesia dan Cina juga memberikan penyediaan barang ke Indonesia yang dibutuhkan masyarakat, serta alat teknologi persenjataan yang dibutuhkan Indonesia.

Mengenai melaksanakan politik luar negeri masa pemerintahan Presiden SBY memiliki sebuah incaran utama yaitu pada Lingkaran Konsentris II. Lingkaran Konsentris II mencakup negara-negara 
Jurnal Pendidikan Pancasila dan Kewarganegaraan

Volume I Nomor 2 (November) 2020

tetangga disebelah selatan (seperti: Australia, Timor Timur dan Selandia Baru) yang bergabung sebagai suatu kemitraan yang strategis. Kemudian melalui pertemuannya dengan kepala-kepala negara Asia-Afrika dalam acara Peringatan 50 tahun KAA, serta mengevaluasi dan membina hubungan lebih baik dengan AS dan UE.

Beberapa catatan mengenai prestasi yang diraih pada masa pemerintahan SBY mengenai politik luar negeri Indonesia adalah Indonesia menjadi pemimpin dalam ASEAN. Kemampuan Indonesia dalam memberikan arahan kepada kegiatan-kegiatan kerjasama dalam APEC, APT, serta bentuk kerjasama ASEAN lainnya. Ikut dalam Bali Democracy Forum (BDF), keikutsertaan TNI dalam menjalankan perdamaian dalam PBB dan pembangunan pusat pelatihan peace keeping force (PKF) di Sentul, serta shuttle diplomacy dan menjadi penengah dalam perseteruan antara Thailand dan Kamboja atas Candi Preah Vihear serta memberikan penampilan peaceoutlook dan democratic outlook Indonesia secara internasional (Situmorang, 2015).

Pada masa pemerintahan SBY (2004-2009) politik luar negeri Indonesia menghadapi beberapa kondisi, diantaranya adalah:

a. Minimnya kemampuan nasional dalam mengatasi masalah krisis ekonomi yang sedang terjadi, sehingga dukungan internasional dalam menghadapi krisis ini sangat diperlukan dan diupayakan dalam pemerintahan SBY.

b. Indonesia harus mencegah perbedaan pandangan dunia internasional mengenai tindakan terorisme internasional yang saat itu banyak berada di Indonesia serta berusaha mendapatkan bantuan dan dukungan dari luar negeri demi mempertahankan keutuhan negara dan bangsa dari berbagai ancaman separatisme dan masalah ekonomi daerah.

c. Peran dan kedudukan Indonesia yang kuat dalam ASEAN untuk mempertahankan kedudukan dan peningkatan kerjasama serta dukungan internasional.

d. Kemudahan dalam berdiplomasi tidak akan kondusif apabila pada era globalisasi tidak dapat meningkatkan citra negara tersebut. Pada pemerintahan SBY diperlukan usaha dalam memulihkan perekonomian dan menjalankan pemeliharaan terhadap pertahanan nasional dan regional yang aman dan stabil. 
Jurnal Pendidikan Pancasila dan Kewarganegaraan

Volume I Nomor 2 (November) 2020

\section{Politik Luar Negeri Indonesia Masa Pemerintahan Joko Widodo}

Pada masa Presiden Jokowi politik luar negeri Indonesia dijalankan berdasarkan pembukaan UUD 1945. Dan dalam melaksanakan kegiatan politik luar negeri Indonesia presiden Joko Widodo telah dibantu oleh kementerian luar negeri, hal ini sudah tertera pada UU no.37 tahun 1999 yang berisi tentang hubungan antara luar negeri. Presiden jokowi merumuskan sebuah kebijakan politik luar negeri, dengan mewujudkan keinginan untuk diplomasi yang berhubungan dengan sifat kerakyatan. Jadi, diartikan dengan langkah untuk mewujudkan diplomasi yang bermasyarakat (Amaliyah, 2015).

Hasil dari kebijakan luar negeri Presiden Joko Widodo yaitu kebijakan politik ke dalam (inward looking). Ada empat argumen yang dikemukakan dalam sebuah politik luar negeri yang cenderung inward looking dan peraturan yang mengatur kebijakannya, yaitu sebagai berikut:

\section{a. Prinsip dan Tujuan Konstitusional Politik Luar Negeri}

Argumentasi yang pertama Presiden Joko Widodo yang menunjukkan peraturan dalam menjalankan politik luar negeri yang ke dalam (inward looking) merupakan kebijakan politik luar negeri yang sudah menjadi prinsip yang dianut oleh para Presiden Indonesia yakni bebas aktif. Kebijakan Presiden Joko Widodo diketahui dalan bentuk visi dan misi dalam menjalani kerjasama dengan luar negeri. Visi tersebut adalah "Terwujudnya Indonesia yang berdaulat, mandiri, dan berkepribadian berlandaskan gotong royong". Visi tersebut memiliki arti kebebasan, jadi Indonesia dapat dengan caranya sendiri menciptakan sebuah kedaulatan, mandiri dan kepribadian nasional. Dalam visi tersebut tercantum juga sikap dan sifat yang aktif untuk mengintegrasikan dalam keikutsertaan Indonesia dalam menjalankan hubungan Internasional dan menjalankan perdamaian dunia.

Pada prinsip politik luar negeri bebas aktif yang diterapkan Indonesia memiliki makna dua. Yang pertama, tujuan dari dilakukannya politik luar negeri Indonesia untuk menjaga identitas nasional. Yang kedua makna dari dilakukannya politik bebas aktif adalah politik luar negeri Indonesia berorientasi untuk mewujudkan harapan dan keinginan nasional yang telah tercantum dalam pembukaan Undang-undang Dasar 1945, keinginan dan 
harapan yaitu menyejahterakan masyarakat Indonesia dan ikut serta dalam menciptakan perdamaian dunia (Situmorang, 2015).

Berdasarkan dari kebijakan bebas aktif dari politik luar negeri Indonesia, dilihat dari tujuan dari kebijakan politik luar negeri Joko Widodo selaras dengan yang dijalankannya. Tujuan tersebut antara lain:

1) Dalam membangun dan melaksanakan kerjasama regional dan kerjasama internasional selalu melihat pada identitas Indonesia yaitu sebagai negara kepulauan.

2) Melalui diplomasi middle power yang membuat Indonesia menjadi sentral dalam kekuatan lokal dan dunia merupakan salah satu usaha meningkatkan posisi global Indonesia.

3) Menjalani hubungan dengan Indonesia Pasifik yang merupakan usaha untuk mendapatkan keterlibatan didalamnya.

4) Menjalankan politik luar negeri Indonesia yang mengikutsertakan masyarakat secara aktif dalam merumuskan kegiatan politik luar negeri Indonesia.

Terdapat empat hal utama yang dipilih Presiden Joko Widodo yaitu: (1) Melindungi Warga Negara Indonesia yang berada diluar negeri, termasuk pekerja yang berada diluar negeri; (2) Perlindungan terhadap SDA serta perdagangan internasional; (3) Produktifitas dalam menjalankan kegiatan ekonomi; (4) Mempertahankan keamanan tingkat nasional, regional serta dunia. Dalam hubungan diplomasi Jokowi mengutamakan penyelesaian potensi sengketa oleh negara-negara di dunia. Jokowi juga memberikan perhatian khusus kepada Palestina berupa memberikan dukungan kemerdekaan di PBB.

\section{b. Konstelasi politik internasional dan regional}

Pada umumnya perubahan politik pada tingkat internasional pada masa pemerintahan Jokowi tidak jauh berbeda dengan pemerintahan Presiden SBY. Hal tersebut menjadikan alasan kedua pemerintahan Joko Widodo menjalankan politik luar negeri Indonesia yang mengutamakan penguatan dalam negeri.

Selain pada isu politik keamanan, perhatian dunia internasional tetaplah pada perekonomian. Dalam hal ini, negara-negara di dunia berusaha meningkatkan kerjasama antar negara untuk 
menciptakan keadaan ekonomi yang stabil dan baik bagi seluruh negara-negara di dunia.

Selain masalah-masalah yang bersifat umum, juga terdapat masalah-masalah yang bersifat spesifik karena dipengaruhi oleh faktor geografis serta pemikiran-pemikiran pragmatis. Pola kegiatan dalam berpolitik dan kegiatan pekonomian di wilayah Asia Tenggara dan Asia sepertinya akan dipengaruhi oleh ASEAN dan juga dipengaruhi oleh munculnya ancaman dari China.

\section{c. Dinamika politik dalam negeri}

Badan legislatif DPR mempunyai tiga tugas utama yaitu regulasi (legislasi), pengangguran, dan pengawasan yang memberikan dampak terhadap pelaksanaan tugas-tugas badan eksekutif yang ditempati oleh presiden. Pemerintahan Joko Widodo dalam politik luar negerinya diwarnai dengan kebijakan hati-hati. Selanjutnya Presiden Joko Widodo juga memilih kebijakan yang tidak kontroversial, karena akan mengakibatkan pada penolakan para anggota DPR. Olah karena itu kebijakan yang yang digunakan adalah sebuah kebijakan yang dapat merebut hati para anggota DPR dengan kebijakan yang dapat memenangkan hati para rakyat. Dengan hal tersebut akan mengurangi perhatian kepada masalahmasalah internasional dikarenakan pemerintahan Joko Widodo bersama para DPR lebih mengedepankan untuk kepentingan dalam negerinya dengan membuat program-program yang ditujukan kepada masyarakat.

\section{d. Idiosinkretisme Jokowi}

Idiosinkretisme menyatakan terdapat empat bagian yang perlu dipahami: cognitive, social perception, motivational, emotional. Dimensi pengetahuan ini memberikan penjelasan tentang pemahaman seseorang pemimpin terhadap (a) berbagai masalah-masalah yang terjadi pada tingkat internasional, (b) hubungan-hubungan yang sedang terjalin misalnya: kerjasama, ketegangan, konflik, perang, dll, (c) identitas, nilai, dan hal penting yang terdapat dalam setiap hubungan internasional, (d) pengaturan- pengaturan, harapanharapan, serta kekuatan-kekuatan yang terdapat didalamnya), dan (e) proses dan pola kerja dalam kegiatan internasional dan nasional (domestic politics). 
Sedangkan pada persepsi sosial mengenai idiosinkretisme memberikan petunjuk terhadap jenis hubungan yang berupa self (diri sendiri) dengan others (orang lain). Sikap sederhana, jujur, terbuka, atau tegas dan berani merupakan hal-hal yang ada pada selfness. Sedangkan penentuan others berdasarkan prioritas kepentingan dan pengetahuan tentang orang lain. Jadi sikap Jokowi yang sederhana dan disiplin sangat membantu dalam menentukan kebijakan-kebijakan mengenai masalah politik luar negeri Indonesia, seperti kegiatan kerjasama yang dilakukan pada bidang perekonomian dan bidang sosial dengan negara-negara lain atau dengan organisasi internasional yang yang baik dan jujur sesuai dengan persepsi yang dimiliki oleh kepemimpinan Presiden Jokowi. Selain itu, ketika menghadapi sebuah negara atau aktor non-negara yang memiliki sikap berlawanan atau melawan kejujuran, maka ketegasan dan keberanian akan muncul pada diri Presiden Joko Widodo. Jokowi menegaskan menggunakan sifat filosofis dan instrumental dalam menjalankan dimensi sosial dari sinkretisme.

Idiosinkretisme pada dimensi motivasional merujuk pada self realization. Sama saja dengan yang terjadi pada presiden-presiden sebelum Jokowi. Kemudian self beliefs atau nilai-nilai dan pandangan tentang sosial merupakan sesuatu hal yang berada pada kehendak para presiden untuk merealisasikan.

Aspek terakhir dari idiosinkretisme adalah emotional. Pengenalan dengan cara menggunakan media terlihat bahwa Jokowi memiliki emosi-emosi positif yang sangat baik bila dibandingkan dengan emosi-emosi negatif. Jokowi memiliki sifat yang cenderung lebih afliasi yang lebih kuat dan emosi yang stabil dan terkendali hal tersebut menurut para pakar psikologis (Taufiqqurrohman, 2014). Di samping itu Presiden Joko Widodo juga memiliki kemampuan intelektual, ketenangan dalam emosi, sikap dan kepribadian dalam melakukan tugasnya menjadi pemimpin

Di samping kemampuan intelektual, ketenangan emosi, karakter, sikap, dan kepribadian dalam memimpin hal tersebut menjadi faktor penentu dalam menjalankan pekerjaannya, seperti kepiawaian dalam berkominikasi, menentukan keputusan, melakukan analisis, mencari penyelesaian yang kreatif (Aco, 2014). 
Pada Pilpres 2019 pasangan capres dan cawapres Jokowi-Ma'ruf merupakan pemenang dari kegiatan pilpres tersebut. Kemudian dalam menjalankan politik luar negeri Indonesia akan tetap melanjutkan prinsip bebas aktif dalam pelaksanaannya. Prinsip bebas aktif ini telah digunakan dari pemerintahan-pemerintahan sebelumnya, seperti juga yang dijalankannya selama hampir lima tahun terakhir bersama wakil presiden Jusuf Kalla.

Seperti halnya prinsip dalam politik luar negeri Indonesia yang menggunakan bebas aktif, pemerintahan Indonesia juga mementingkan keberlanjutan dari kerjasama dengan negara China dan Amerika Serikat. Dimana China dan Amerika Serikat disebut dengan julukan dua raksasa ekonomi yang terlibat dalam perang dagang. Kerjasama tersebut setidaknya berlangsung selama masa pemerintahan lima tahun ke depan.

Selama peraturan yang diberikan China untuk melaksanakan investasi di Indonesia ini tidak membuat rugi rakyat yang bermaksud tidak mengambil kesempatan kerja rakyat Indonesia, maka dapat dikatakan bahwa kerjasama RI dengan China tidak akan bermasalah. Namun berbeda, jika keadaan dan jumlah kesempatan kerja yang ada malah dikuasai oleh tenaga kerja dari China, peristiwa itu akan menjadi sebuah masalah mengenai ketenagakerjaan yang besar di kemudian hari.

Selain dengan China, Indonesia juga harus menjaga dan membangun kerjasama dengan Amerika Serikat. Dalam menjalin kerjasama, Indonesia tetap menjaga hubungannya dengan baik dan tidak mengutamakan salah satu negara saja meskipun saat itu Amerika Serikat dengan China sedang terjadi perang dagang. Indonesia harus menjaga kerjasama dengan China, karena China merupakan negara besar di wilayah Asia. Sedangkan Amerika Serikat merupakan negara adidaya di dunia.

Penguatan terhadap pertahanan perlu dilaksanakan dengan memberikan kenaikan anggaran pada tiap tahunnya, karena merupakan sebuah kebijakan yang harus dilakukan untuk sistem pertahanan. Selain itu juga harus menciptakan pada kekuasaan pada maritim, agar maritim Indonesia kuat dan selatan dapat bersiap siaga serta dihormati oleh negara-negara lain.

Dalam melaksanakan politik luar negeri Indonesia yang selanjutnya yaitu masa pemerintahan Jokowi tahap dua, juga sangat diperlukan kehati-hatian serta ketelitian Pemerintah Indonesia pada 
Jurnal Pendidikan Pancasila dan Kewarganegaraan

Volume I Nomor 2 (November) 2020

beberapa isu domestik yang mempunyai pengaruh untuk dunia Internasional.

Sedangkan dalam mengatasi pengembangan perekonomian lokal dan juga untuk perekonomian dunia internasional yang diwarnai dengan dinamika dimana presiden bersama dengan menteri-menteri dituntut untuk melaksanakan pemerintahan. Kegiatan ekonomi lokal yang dimaksud merupakan keadaan ekonomi nasional yang harus berkembang sejalan dengan perkembangan ekonomi Internasional. Keberhasilan kegiatan ekonomi nasional dapat ditentukan berdasarkan beberapa hal berikut ini: pendapatan perkapita, seberapa laju inflasi, tingkat perolehan memproduksi, serta tingkat pengangguran dan kemiskinan, selain faktor dalam negeri perekonomian Indonesia juga terdapat faktor perekonomian dari luar negeri yaitu mencakup internasional.

Berbicara mengenai usaha untuk mengedepankan ekonomi nasional, dianjurkan bersikap optimis serta mengharap akan perbaikan dan kemudian dari kegiatan ekonomi internasional, hal tersebut disampaikan oleh Presiden Joko Widodo dalam beberapa peluang. Sikap optimis dalam menjalankan kegiatan ekonomi perlu didukung dari berbagai pihak supaya kegiatan dalam perekonomian nasional tidak ketinggalan dan terus berkembang. Sehingga dapat memberikan pengaruh yang lebih signifikan dalam melaksanakan kegiatan politik luar negeri Indonesia yang bersifat bebas aktif (Syafaat, 2019).

Kehidupan pemerintahan Republik Indonesia pada masa Presiden Joko Widodo dan Wakil Presiden Ma'ruf Amin tentu sangat diperlukan akan adanya usaha pertahanan terhadap politik luar negeri yang berprinsip bebas aktif secara tetap tanpa meninggalkan kepentingan nasional, yang dalam hal ini aspirasi masyarakat juga sangat diperlukan.

\section{KESIMPULAN}

Sejarah perkembangan politik luar negeri Indonesia masa pasca reformasi dimulai pada saat masa pemerintahan B. J. Habibie, beberapa kebijakan dalam pemerintahannya yang membedakan dengan masa sebelum reformasi yaitu memberikan dukungan terhadap kebebasan pers, liberalisasi partai-partai politik, meningkatkan dan melanjutkan kerja sama bersama organisasi yang bersifat multilateral. Dilanjut, dengan masa pemerintahan Abdurrahman Wahid, kebijakan politik luar negeri yang 
dilakukan sering kali menjadi sorotan publik hingga munculnya kritikan. Seperti, kunjungan ke lima benua, kritikan muncul dari ketua MPR Amin Rais dan ketua DPR Akbar Tandjung karena dirasa kurang memperhatikan masalah domestik, seperti konflik aceh. Namun Gus Dur menjawab bahwa kunjungannya ke luar negeri bertujuan untuk mengembalikan nama baik Indonesia, berharap investor internasional menanamkan modal lagi, dan mencari dukungan internasional terhadap keutuhan Aceh yang merupakan bagian dari NKRI. Berbeda dengan masa Gus Dur, yang mana peran presiden lebih dominan dalam pelaksanaan politik luar negeri. Megawati lebih banyak melimpahkan tugas diplomasi dan tugas menjalankan politik luar negeri kepada menteri luar negerinya. Dalam pelaksanaan politik luar negerinya, ia memprioritaskan dan memegang teguh prinsip yang selama ini dipegang dalam melaksanakan politik luar negeri yakni prinsip bebas aktif, mengembalikan martabat bangsa dan negara di mata dunia, serta mengembalikan kepercayaan luar negeri terhadap Indonesia termasuk lembaga-lembaga pemberi pinjaman kepada Indonesia dan investor terhadap kegiatan pemerintah. Selanjutnya, masa pemerintahan SBY dalam pelaksanaan politik luar negeri. Presiden SBY memiliki sebuah incaran utama yaitu pada Lingkaran Konsentris II. Lingkaran Konsentris II mencakup negara-negara tetangga disebelah selatan (seperti: Australia, Timor Timur dan Selandia Baru) yang bergabung sebagai suatu kemitraan yang strategis. Dan selanjutnya pemerintahan Joko Widodo, politik luar negerinya diwarnai dengan kebijakan hati-hati. Presiden Joko Widodo juga memilih kebijakan yang tidak kontroversial, karena akan mengakibatkan pada penolakan para anggota DPR. Oleh karena itu kebijakan yang digunakan adalah sebuah kebijakan yang dapat merebut hati para anggota DPR dengan kebijakan yang dapat memenangkan hati rakyat. Dengan hal tersebut akan mengurangi perhatian kepada masalahmasalah internasional dikarenakan pemerintahan Joko Widodo bersama para DPR lebih mengedepankan untuk kepentingan dalam negerinya dengan membuat program-program yang ditujukan kepada masyarakat.

Setiap masa pemerintahan, presiden sebagai pemimpin negara sekaligus pemimpin pemerintahan berupaya semaksimal mungkin dalam membuat dan menyusun strategi dalam pelaksanaan politik luar negerinya. Perjuangan dalam menjalankan pemerintahan Indonesia akan terus berjalan. Pengalaman terhadap peristiwa reformasi yang terjadi di Indonesia membuat sadar dari berbagai pihak bahwa sangat diperlukan 
Jurnal Pendidikan Pancasila dan Kewarganegaraan

Volume I Nomor 2 (November) 2020

perbaikan di segala bidang, guna untuk mendapatkan respon yang cepat dan tepat dalam menjawab berbagai tantangan zaman.

Mengingat setiap masa akan mempunyai berbagai dinamika situasi domestik maupun global, begitupun dengan kebijakan di setiap masa tersebut. Penelitian ini pun perlu adanya penyempurnaan dari penelitian selanjutnya sehingga pembaharuan ilmu pengetahuan akan terus berlanjut.

\section{UCAPAN TERIMA KASIH}

Syukur Alhamdulillah senantiasa kami ucapkan seiring terselesainya artikel yang berjudul "Sejarah Perkembangan Politik Luar Negeri Indonesia Masa Pasca Reformasi" ini, terimakasih kami ucapkan kepada Dosen Pembimbing kami Bapak Depict Pristine Adi, M. Pd. I yang telah sudi meluangkan waktunya membimbing kami, mengenalkan kami pada dunia kepenulisan. Tak lupa pula kepada editor dan reviewer jurnal JPPKN yang telah menjadikan artikel ini menjadi layak terbit.

\section{DAFTAR PUSTAKA}

Ansyari, Syahrul. (2019). Sejarah B. J. Habibie dan Sejarah Referendum

Timor Timur. Vivanews. diakses tanggal 14 Mei 2020 pada https://www.vivanews.com/berita/nasional/6822-bj-habibie-dansejarah-referendum-timor-timur?medium=autonext.

Elisabet, Adriana. (2016). Grand Desain Kebijakan Luar Negeri Indonesia (2015-2025). Jakarta: Yayasan Pustaka Obor Indonesia \& LIPI.

Hamonangan, Iskandar. (2018). Reformasi Menuju Demokrasi: Kebijakan luar negeri masa presidensi B.J Habibie. Diakses 13 Mei 2020 pada http://irec-id.org/wp-content/uploads/2018/12/Reformasi-Menuju-

Demokrasi-Kebijakan-luar-negeri-masa-presidensi-B.J-Habibie

Hasanuddin Aco. (2014). Pakar Psikologis: Capres Harus Memiliki Emosi Stabil. Tribunnews. Diakses 5 Maret 2020 pada https://www.tribunnews.com/pemilu-2014/2014/05/23/pakarpsikologis-capres-harus-memiliki-emosi-stabil.

Hidayat, Wisnu Amri dan Iswara N. (2019). Sejarah Timor Timur Bergabung dengan NKRI dan Peran Amerika Serikat. Tirto.id. diakses 14 Mei 2020 pada https://tirto.id/sejarah-timor-timurbergabung-dengan-nkri-peran-amerika-serikat-eesp.

Junaidi, Eko Wahyu dan Saefur Rochmat. (2018). Hubungan Indonesia Australia Pada Masa Presiden Megawati Soekarnoputri (2001-2004), Jurnal Pendidikan Sejarah 5(1), 16-20. 
Jurnal Pendidikan Pancasila dan Kewarganegaraan

Volume I Nomor 2 (November) 2020

http://journal.student.uny.ac.id/ojs/index.php/risalah/article/view/12 $\underline{432}$.

Mohsen, Aiyub. (2019). Politik Luar Negeri Republik Indonesia Masa Lampau, Kini dan Masa Depan: Suatu Tinjauan dan Saran Kedepan. Jurnal Ilmu dan Budaya, 41(62), 7228. http://journal.unas.ac.id/ilmubudaya/article/view/655.

Pramono, Suwito Eko. (2014). Kinerja Guru Sejarah: Studi Kausal pada Guru-Guru Sejarah SMA di Kota Semarang. Jurnal Paramita 24 (1), 114.

Rachmianto, Andy. Politik Luar Negeri Pemerintahan Megawati. Perpustakaan Bappenas. diakses 15 Mei 2020 pada http://perpustakaan.bappenas.go.id/lontar/file?file=digital/blob/F144 35/Politik\%20Luar\%20Negeri\%20Pemerintahan.htm.

Rif'ah, Erwin Nur. (2016). Pengaruh Personality Politics Abdurrahman Wahid Terhadap Politik Luar Negeri Indonesia. Repository UNEJ. $\begin{array}{lllll}\text { diakses } & 13 & \text { Mei } & 2020 & \text { pada }\end{array}$ http://repository.unej.ac.id/handle/123456789/75532.

Sari, Cut Maya Aprita. (2018). Perubahan Sistem Politik Indonesia Pasca Reformasi 1998, Keadilan Sosial, dan Deficit Demokrasi Hingga Kini. $\begin{array}{lllll}\text { diakses } & 14 & \text { Mei } & 2020 & \text { pada }\end{array}$ https://www.researchgate.net/publication/327668175 Perubahan Sist em Politik Indonesia Pasca Reformasi 1998 Keadilan Sosial dan Deficit Demokrasi Hingga Kini.

Setiadi, Elly. M. dan Usman Kolip. (2013). Pengantar Sosiologi Politik. Jakarta: Kencana.

Setiawan, Samhis. (2020). Studi Kepustakaan: Pengertian, tujuan, peranan, dan strategi. Guru Pendidikan. Diakses 5 Maret 2020 pada https://www.gurupendidikan.co.id/studi-kepustakaan-pengertiantujuan-peranan-sumber-strategi/.

Siska, Yulia. (2015). Sejarah Politik. Jakarta: YWS Wacana.

Situmorang, Mangadar. (2015). Orientasi Kebijakan Politik Luar Negeri Indonesia di bawah Pemerintahan Jokowi-JK. Jurnal Ilmiah Hubungan Internasional, $11(1)$, 68. http://journal.unpar.ac.id/index.php/JurnalIlmiahHubunganInternasi ona/article/view/1442.

Sudarso, Navira Ariani. (2012). Gaya Perpolitikan Dan Dominasi Politik Luar Negeri Gus Dur. diakses 14 Mei 2020, https://www.kompasiana.com/veyosarian/550ffc998133119f36bc60d4 
Lpolitik-luar-negeri-indonesia-gaya-perpolitikan-dan-dominasipolitik-luar-negeri-gus-dur.

Sugiyono. (2012). Metode Penelitian Kuantitatif Kualitatifdan RED. Bandung: Alfabeta.

Syafaat, Aat Surya. (2019). Arah Kebijakan Luar Negeri Jokowi-Ma'ruf. Antara Banten. Diakses 5 Maret 2020 pada https://banten.antaranews.com/berita/52470/arah-kebijakan-luarnegeri-jokowi-maruf.

Taufiq, Muhammad. (2013). Mengapa Gus Dur dengan Yahudi. Merdeka.com. diakses tanggal 16 Mei 2020 pada https://www.merdeka.com/peristiwa/mengapa-gus-dur-dekatdengan-yahudi.html.

Taufiqqurrohman. (2014). Survei Psikologi: Motivasi Berkuasa Prabowo Paling Tinggi. Liputan 6. Diakses 5 Maret 2020 pada https://www.liputan6.com/indonesia-baru/read/2072710/surveipsikologi-motivasi-berkuasa-prabowo-paling-tinggi.

Undang-Undang Nomor 37 tahun 1999 tentang Hubungan Luar Negeri Tahun 1999. Pada tanggal 14 September 1999.

Wilianto, Ari. (2020). Politik Luar Negeri Indonesia. diakses tanggal 24 Agustus 2020 pada https://www.kompas.com/skola/read/2020/03/05/200000469/politikluar-negeri-indonesia?page=all.

Widhiyoga, Ganjar \& Setyasih Harini. (2019). Identitas Politik Luar Negeri Indonesia di Masa Reformasi (1999-2014). Research Fair Unisri, 3(1), 568-569. http://ejurnal.unisri.ac.id/index.php/rsfu/article/view/2618.

Wisnu, Dinna. (2018). Politik Luar Negeri Pasca-Reformasi. Sindonews. $\begin{array}{lllll}\text { diakses } & 14 & \text { Mei } & 2020 & \text { pada }\end{array}$ https://nasional.sindonews.com/berita/1308093/18/politik-luarnegeri-pasca-reformasi.

Yani, Yanyan Moh dan Ian kontra Tama. (2017). Quo Vadis Politik Luar Negeri Indonesia. Jakarta: PT Elex Media Komputindo.

Zakky. (2018), "Pengertian Politik Luar Negeri Menurut Para Ahli dan Secara Umum," Zonareferensi, diakses 28 Juli 2020, https://www.zonareferensi.com/pengertian-politik-luar-negeri/. 